\title{
Arteriovenous fistulas for microvascular head and neck reconstruction
}

\author{
Sami P Moubayed MD¹, Jean-Philippe Giot MD PhD², Andrei Odobescu MD², Louis Guertin MD¹, \\ Patrick G Harris $\mathrm{MD}^{2}$, Michel Alain Danino MD PhD²
}

\begin{abstract}
SP Moubayed, J-P Giot, A Odobescu, L Guertin, PG Harris, MA Danino. Arteriovenous fistulas for microvascular head and neck reconstruction. Plast Surg 2015;23(3):167-170.
\end{abstract}

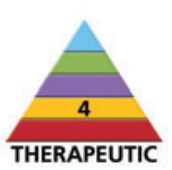

BACKGROUND: In head and neck cancer patients, multiple surgeries and radiation can leave the neck depleted of recipient vessels appropriate for microvascular reconstruction. The creation of temporary arteriovenous fistulas using venous interposition for subsequent microvascular reconstruction has rarely been reported in the head and neck. The authors report the largest series of temporary arteriovenous loops for head and neck reconstruction in vessel-depleted necks.

METHODS: The authors performed a case series of major head and neck reconstructions using temporary arteriovenous fistulas with a saphenous vein graft. A subclavian surgical approach was used. All reconstructions were performed at least two weeks after the creation of the initial fistula. RESULTS: The authors have performed nine reconstructive cases for malignancy using five different free flaps. The subclavian and transerve cervical arteries were used, and the subclavian, internal jugular and cephalic veins were used for microanastomosis. Two cases of flap hematoma and one case of venous pedicle compression were recorded. No cases of flap failure were reported.

CONCLUSIONS: Reconstruction using temporary arteriovenous fistulas is a reliable technique that can be used in the vessel-depleted neck, with excellent outcomes in experienced hands.

Key Words: Flap; Head and neck cancer; Microsurgery; Radiation therapy; Reconstruction; Surgical arterioveinous fistula

$\mathrm{M}$ ajor head and neck defects are often the result of ablative surgery for squamous cell carcinoma, and microvascular reconstruction with vascularized tissue has greatly improved the functional and quality of life outcomes of these patients (1). For free tissue transfer to be successful, proper vessel selection is essential (1). Unfortunately, recurrent disease and second primary malignancies are a persistent problem, and often occur after adjuvant chemoradiation (2). These patients often undergo one, two or three surgeries following the initial therapy to manage recurrent disease, a second primary malignancy or a complication of chemoradiation (2). In these patients, multiple surgeries and radiation can leave the neck depleted of recipient vessels appropriate for microvascular reconstruction (2).

The creation of temporary arteriovenous fistulas using venous interposition for subsequent microvascular reconstruction were initially described in 1982 by Threlfall et al (3). This technique has been reported by several authors in difficult microsurgical flap cases in all body regions; however, $<15$ cases have been reported in the head and neck (4-9). Our aim was to report the largest series of temporary arteriovenous loops for head and neck reconstruction in vesseldepleted necks.

\section{METHODS}

After institutional review board approval, a retrospective case series was conducted on all cases of head and neck defects reconstructed with a

\section{Des fistules artérioveineuses pour une reconstruction de la tête et du cou}

HISTORIQUE : Chez les patients atteints d'un cancer de la tête et du cou, les multiples opérations et la radiothérapie peuvent expurger le cou des vaisseaux receveurs convenant à la reconstruction microvasculaire. La création de fistules artérioveineuses temporaires par interposition veineuse en vue d'une reconstruction microvasculaire a rarement été signalée sur la tête et le cou. Les auteurs rendent compte de la plus vaste série de cas de boucles artérioveineuses temporaires sur des cous expurgés de vaisseaux receveurs lors de la reconstruction de la tête et du cou.

MÉTHODOLOGIE : Les auteurs ont procédé à une série de cas de reconstructions majeures de la tête et du cou au moyen de fistules artérioveineuses temporaires par greffe de la veine saphène, en privilégiant un abord par la sous-clavière. Ils ont effectué toutes les reconstructions au moins deux semaines après la création de la fistule initiale.

RÉSULTATS : Les auteurs ont effectué neuf reconstructions au moyen de cinq lambeaux libres différents après un cancer. Ils ont utilisé les artères sous-clavière et cervicale transverse ainsi que les veines sous-clavière, jugulaire interne et céphalique pour la micro-anastomose. Ils ont enregistré deux cas d'hématome du lambeau et un cas de compression du pédicule, mais aucun cas d'échec du lambeau.

CONCLUSIONS : Entre des mains expérimentées, la reconstruction au moyen de fistules artérioveneuses temporaires est une technique fiable qui peut être utilisée dans le cou expurgé de vaisseaux receveurs et donner d'excellents résultats.

temporary arteriovenous fistula between June 2004 and August 2014 Patient demographic data are reported as sex, age, American Society of Anesthesiologists Physical Status classification and the surgical indication. Surgical details are presented as fistula length, recipient artery and vein, type of flap and weeks between flap stages. Surgical outcomes are reported as minor complications, major complications and flap failures. Major complication was defined as a complication that required return to the operating room. Flap failure was defined as total flap necrosis.

\section{Surgical technique}

The patient is placed in dorsal decubitus positioning with a shoulder roll, and the head rotated to the opposite side in slight extension to expose the root of the neck. A subclavian approach is performed (10). A $10 \mathrm{~cm}$ to $12 \mathrm{~cm}$ skin incision is positioned approximately $2 \mathrm{~cm}$ above and parallel to the clavicle. The incision is extended to the midline inferiorly toward the sternoclavicular articulation (Figure 1). The platysma is incised and a subplatysmal flap is reclined superiorly. The clavicular head of the sternocleidomastoid is incised and retracted superiorly to expose the lymphatic tissue, which is mobilized superiorly along with the incised omohyoid muscle. The anterior scalene and the overlying phrenic nerve, along with the brachial plexus, are exposed behind the prevertebral fascia. The phrenic nerve is skeletonized, and the terminal portion of the anterior scalene is resected to expose the

${ }^{1}$ Otolaryngology-Head and Neck Surgery Service; ${ }^{2}$ Plastic Surgery Service, Department of Surgery, Université de Montréal Hospital Center (CHUM), Montreal, Quebec

Correspondence: Dr Michel Alain Danino, Hôpital Notre-Dame, CHUM, 1560 Sherbrooke East, Montreal, Quebec H2L 4M1.

Telephone 514-890-8000 ext 26808,e-mail michel.alain.danino@umontreal.ca 


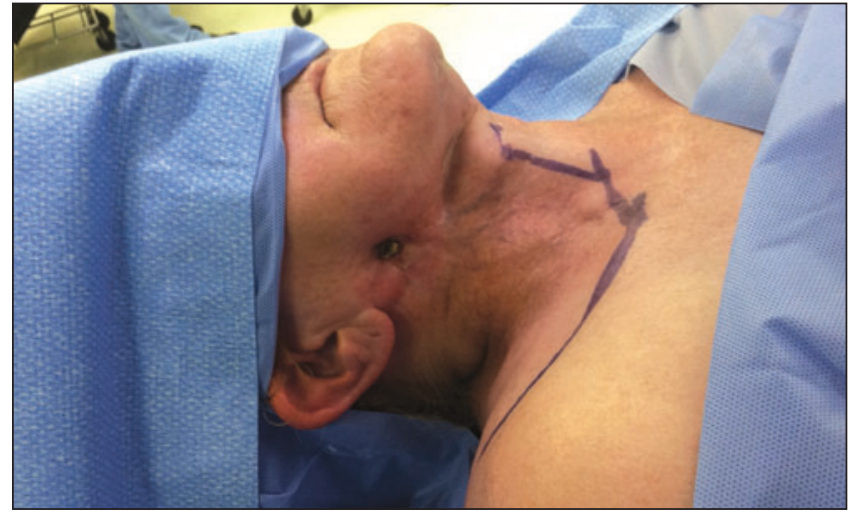

Figure 1) Standard subclavian surgical approach
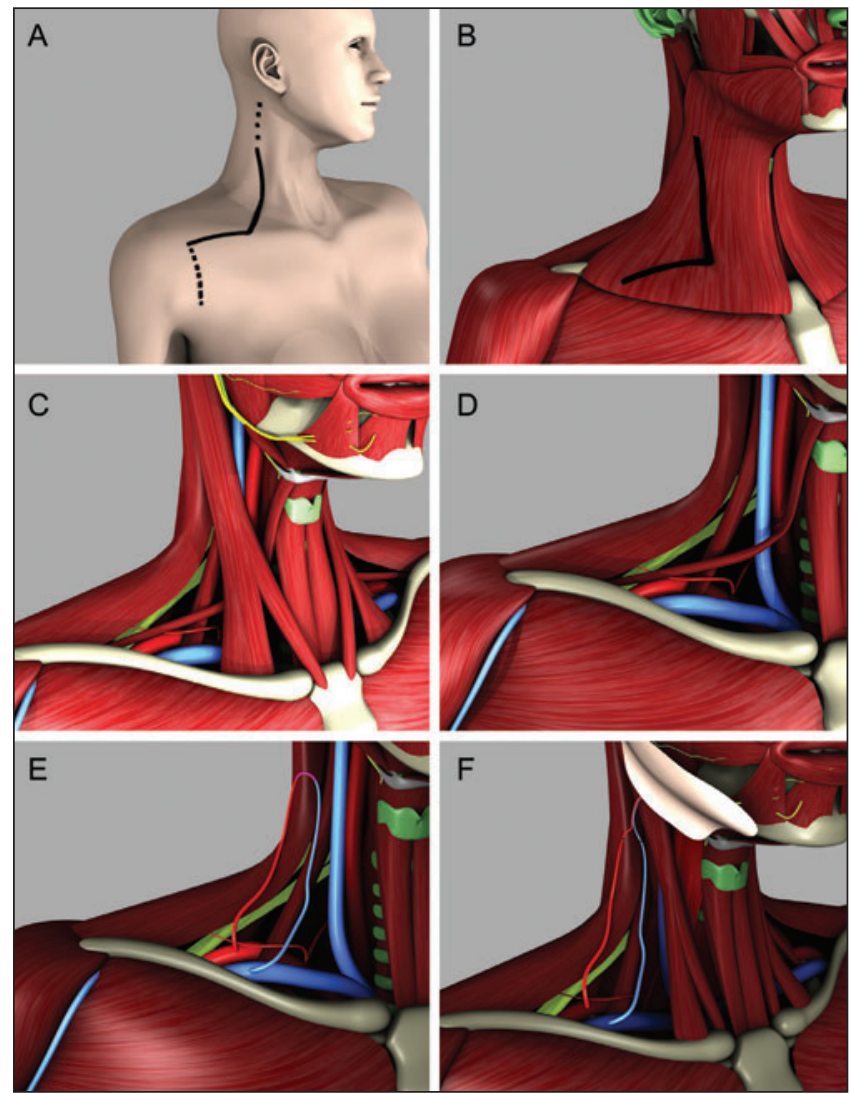

Figure 2) Three-dimensional rendering of the steps in free flap reconstruction using a temporary arteriovenous fistula: markings (A), platysmal division (B), identification of omohyoid and division (C), identification of subclavian vessels (D), creating of temporary arteriovenous fistula (E), flap inset (F)

subclavian artery and vein. The thyrocervical trunk may be encountered and its arteries used as recipient vessels. The subclavian vessels may then be placed behind vessel loops to perform anastomoses. The surgical approach is summarized in Figure 2. A saphenous vein is harvested in a standard fashion (11), and is typically anastomosed in a terminolateral fashion on the subclavian artery and vein (Figure 3 ). The patient is placed on intravenous heparin protocol for two weeks to achieve a partial thromboplastin time between $50 \mathrm{~s}$ and $74 \mathrm{~s}$ ( 2 to 2.5 times the normal value of $22 \mathrm{~s}$ to $30 \mathrm{~s}$ ) and heparin was progressively tapered over a $72 \mathrm{~h}$ period. At least two weeks after the initial fistula creation, the neck is re-explored, and a free flap is anastomosed onto the previously created fistula (Figure 4).

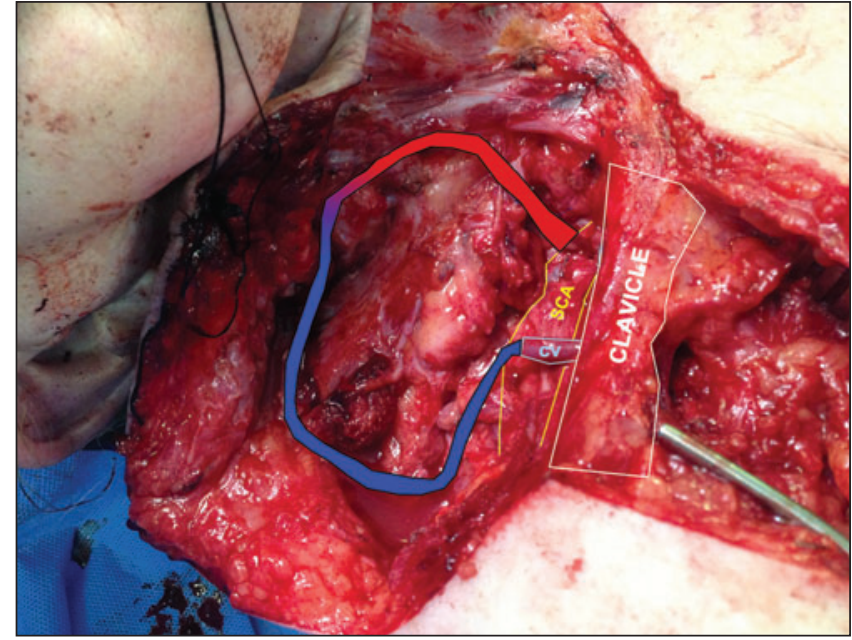

Figure 3) Fistula creation after saphenous vein harvest. CV Cephalic vein; SCA Subclavian artery

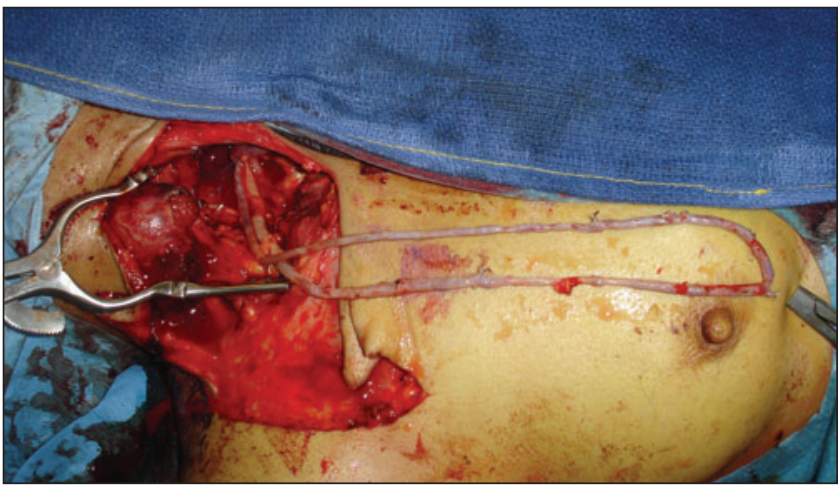

Figure 4) Arteriovenous fistula creation in another patient shown exposed on the patient's chest

\section{RESULTS}

The authors performed nine head and neck reconstructions using temporary arteriovenous fistulas during the study period. Patient demographic data are presented in Table 1.

Surgical details are presented in Table 2. Fistula length for patient 7 was, unfortunately, not available because it was not recorded in the medical chart, although it measured a minimum of $15 \mathrm{~cm}$. All reconstructions were performed at least two weeks after the creation of the initial fistula.

Surgical outcomes are reported in Table 3. No cases of flap failure were reported. Two patients suffered from a venous hematoma that was drained without return to the operating room, and these patients remained under therapeutic anticoagulation with partial thromboplastin times 2 to 2.5 times the normal values. A third patient suffered from a hematoma causing pedicle compression, which was was evacuated in the operating room

Cosmetic outcomes were adequate for all patients, with an example shown in Figure 5.

\section{DISCUSSION}

We have successfully reported the largest case series of head and neck reconstruction using temporary arteriovenous fistulas. We show that this is a reliable technique in the vessel-depleted neck with no cases of flap failure in our 10 years of experience. Multiple flap options may be used, and most anastomoses are performed in a termino-lateral fashion on the subclavian vessels.

The indications for this technique remain limited, which is reflected by the scarce number of cases in the literature. Other alternatives have been described for vessel selection in the vesseldepleted neck (12), which include vessels from the contralateral neck, vessels outside of the head and neck (internal mammary artery, 
TABLE 1

Patient demographic data and surgical indications

\begin{tabular}{lcccl}
\hline \multicolumn{5}{c}{ Age, } \\
Patient & Sex years & ASA & Surgical indication \\
\hline 1 & F & 53 & 1 & $\begin{array}{l}\text { Postradiation and neck dissection facial paralysis } \\
2\end{array}$ \\
& M & 57 & 2 & $\begin{array}{l}\text { Postradiation and neck dissection mucocutaneous } \\
\text { fistula }\end{array}$ \\
3 & M & 66 & 2 & Postradiation and neck dissection \\
4 & M & 47 & 1 & Postradiation scalp defect \\
5 & M & 44 & 1 & Postradiation scalp defect \\
6 & F & 45 & 3 & Post-neck dissection mandibular osteoradionecrosis \\
7 & F & 65 & 2 & Post-neck dissection mandibular osteoradionecrosis \\
8 & F & 34 & 1 & Dermatofibrosarcoma protuberens of scalp \\
9 & F & 55 & 1 & Dermatofibrosarcoma protuberens of scalp
\end{tabular}

ASA American Society of Anesthesiologists score; F Female; M Male

TABLE 2

Surgical details

\begin{tabular}{|c|c|c|c|c|c|}
\hline Patient & $\begin{array}{c}\text { Fistula } \\
\text { length, } \\
\mathbf{c m}\end{array}$ & Artery & Vein & Flap & $\begin{array}{l}\text { Weeks } \\
\text { between } \\
\text { stages }\end{array}$ \\
\hline 1 & 27 & Subclavian (T-L) & Subclavian (T-L) & Gracilis & 2 \\
\hline 2 & 23 & Subclavian (T-L) & Subclavian (T-L) & $\begin{array}{l}\text { Radial } \\
\text { forearm }\end{array}$ & 2 \\
\hline 3 & 35 & $\begin{array}{l}\text { Transverse } \\
\text { cervical (T-T) }\end{array}$ & IJV (T-T) & ALT & 3 \\
\hline 4 & 36 & Subclavian (T-L) & Subclavian (T-L) & LD & 3 \\
\hline 5 & 32 & Subclavian (T-L) & Subclavian (T-L) & LD & 4 \\
\hline 6 & 37 & $\begin{array}{l}\text { Transverse } \\
\text { cervical (T-T) }\end{array}$ & IJV (T-L) & $\begin{array}{l}\text { Radial } \\
\text { forearm }\end{array}$ & 7 \\
\hline 7 & $-^{\star}$ & $\begin{array}{l}\text { Transverse } \\
\text { cervical (T-T) }\end{array}$ & Cephalic (T-L) & $\begin{array}{l}\text { Radial } \\
\text { forearm }\end{array}$ & 8 \\
\hline 8 & 21 & Subclavian (T-L) & Subclavian (T-L) & LD & 3 \\
\hline 9 & 23 & Subclavian (T-L) & Subclavian (T-L) & Groin flap & 3 \\
\hline
\end{tabular}

*Fistula length was not recorded. ALT Anterolateral thigh; IJV Internal jugular vein; LD Latissimus dorsi; T-L Termino-lateral; T-T Termino-terminal

TABLE 3

Surgical outcomes

\begin{tabular}{lccc}
\hline & \multicolumn{2}{c}{ Complication } & \\
\cline { 2 - 3 } Patient & Minor & Major & Flap failure \\
\hline 1 & None & None & None \\
2 & None & None & None \\
3 & None & None & None \\
4 & None & None & None \\
5 & Flap hematoma & None & None \\
6 & Flap hematoma & None & None \\
7 & None & None & None \\
8 & None & None & None \\
9 & None & Venous pedicle & None \\
& & compression &
\end{tabular}

thoracoacromial artery, cephalic vein) or vein grafting. All of these options are viable alternatives and their selection depends on the individual surgeon's preference.

Technical difficulties we have encountered in our experience include exposure in the subclavian approach, which requires comfort operating at the base of the neck. Operating in a multioperated and irradiated neck also requires great caution due to previous scar formation and vessel friability. However, secondary dissection was always possible with good arterialization of the saphenous graft.

An interesting alternative to saphenous vein grafting is the cephalic vein transposition to the arterial system with secondary division

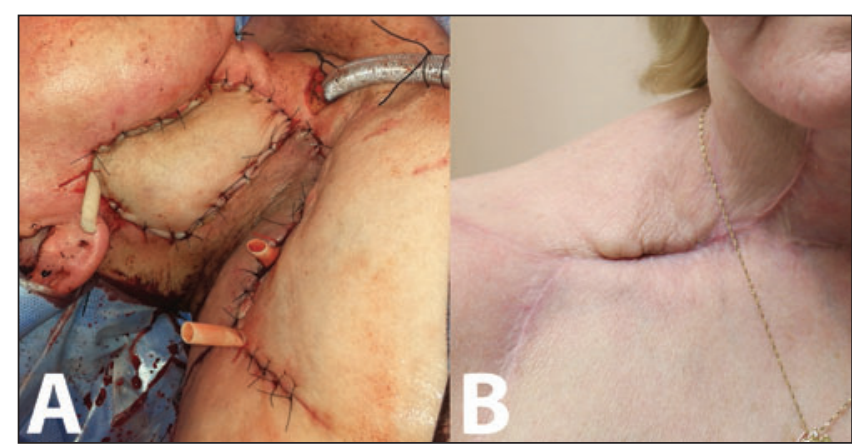

Figure 5) Second stage flap harvest and inset (A) with results at three months (B)

TABLE 4

Other reported series of head and neck reconstruction using microvascular fistula

\begin{tabular}{|c|c|c|c|c|}
\hline Reference & $\begin{array}{c}\text { Patients, } \\
\mathbf{n}\end{array}$ & Stages & Complications & Failures \\
\hline $\begin{array}{l}\text { Ethunandan et al, } \\
2007 \text { (5) }\end{array}$ & 1 & Single-staged & None & None \\
\hline Kim et al, 1998 (6) & 1 & Single-staged & Venous thrombosis & None \\
\hline $\begin{array}{l}\text { Oswald et al, } 2007 \\
\text { (9) }\end{array}$ & 4 & Single-staged & $\begin{array}{l}\text { Partial breakdown } \\
\text { (1 of } 4)\end{array}$ & None \\
\hline $\begin{array}{l}\text { Mulholland et al, } \\
1993 \text { (8) }\end{array}$ & 5 & Single-staged & None & $\begin{array}{l}\text { One failure } \\
\text { (1 of } 5)\end{array}$ \\
\hline $\begin{array}{l}\text { Depprich et al, } \\
2008 \text { (4) }\end{array}$ & 1 & Two-staged & None & None \\
\hline Lind et al, 2012 (7) & 2 & Two-staged & None & None \\
\hline
\end{tabular}

and microvascular anastomosis, also known as the Corlett loop (5). The advantage of this technique is the requirement of a single anastomosis for fistula creation, which minimizes flap failure. However, this technique requires a long scar in the upper chest and arm, and requires particular attention to vessel orientation to avoid twisting them.

Controversy exists in the literature as to whether it is preferable to perform this technique in a single-stage or two-stage fashion. Advantages of the single-stage technique include the avoidance of a second procedure under general anesthesia, as well as the avoidance of operating in a multioperated neck with scar formation. However, the theoretical advantage of the two-stage technique is arterialization of the vein, which could avoid adverse flap outcomes. A recent metaanalysis compared all published reports of one-stage (109 patients) and two-stage operations (83 patients), regardless of the anatomical site involved (9). The authors found no difference in flap outcomes between the two types of procedures. To our knowledge, this is the largest series of head and neck reconstruction using temporary arteriovenous fistulas (Table 4). The only failure reported in the literature using microvascular fistulas was in a patient who underwent a onestage technique (8). However, the total number of patients reported in the literature is very low, and we cannot interpret this as being due to the technique itself.

However, we believe that it is possible that the numbers reported for each series are low, and demonstrating statistically that one of the techniques is superior may be difficult due to inclusion bias, and the rarity of this type of surgery. We believe the two-stage technique to be superior and have not experienced a single failure in 10 years of using this technique.

\section{CONCLUSIONS}

Head and neck microvascular reconstruction using temporary arteriovenous fistulas is a reliable technique to be used in the vessel-depleted neck, with excellent outcomes in experienced hands. Indications for this technique are limited, data in the head and neck are scarce, and 
although there is a theoretical advantage of a two-staged technique, this has yet to be proven by studies with a large sample size.

DISCLOSURES: The authors have no financial disclosures or conflicts of interest to declare. Presented at the 68th Annual Meeting of the Canadian Society of Plastic Surgeons in Montréal, Québec, June 24, 2014.

\section{REFERENCES}

1. Yazar S. Selection of recipient vessels in microsurgical free tissue reconstruction of head and neck defects. Microsurgery 2007;27:588-94.

2. Jacobson AS, Eloy JA, Park E, et al. Vessel-depleted neck: Techniques for achieving microvascular reconstruction. Head Neck 2008;30:201-7.

3. Threlfall GN, Little JM, Cummine J. Free flap transfer preliminary establishment of an arteriovenous fistula: A case report. Austral NZ J Surg 1982;52:182-4.

4. Depprich RA, Naujoks CD, Meyer U, et al. Ateriovenous subclavia-shunt for head and neck reconstruction. Head Face Med 2008;4:27.
5. Ethunandan M, Cole R, Flood TR. Corlett loop for microvascular reconstruction in a neck depleted of vessels. Br J Oral Maxillofac Surg 2007;45:493-5.

6. Kim KA, Chandrasekhar BS. Cephalic vein in salvage microsurgical reconstruction in the head and neck. Br J Plast Surg 1998;51:2-7.

7. Lind B, McCarthy W, Derman G, et al. Arteriovenous loop grafts for free tissue transfer. Vasc Endovasc Surg 2012;46:30-3.

8. Mulholland S, Boyd JB, McCabe S, et al. Recipient vessels in head and neck microsurgery: Radiation effect and vessel access. Plast Reconstr Surg 1993;92:628-2.

9. Oswald TM, Stover SA, Gerzenstein J, et al. Immediate and delayed use of arteriovenous fistulae in microsurgical flap procedures: A clinical series and review of published cases. Ann Plast Surg 2007;58:61-3.

10. Kilinc A, Laurian C. [Résection de la première côte par voie sus et sous claviculaire dans le traitement du syndrome du défilé thoracocervico-brachial]. 2014.<http://sdtb.blogspot.ca/2009/05/resectionde-la-premiere-cote-par-voie.html> (Accessed May 21, 2015).

11. Iafrati MM. Less-invasive saphenous harvest. Surg Clin N Am 1999;79:623-44.

12. Chia HL, Wong CH, Tan BK, et al. An algorithm for recipient vessel selection in microsurgical head and neck reconstruction. J Reconstructr Microsurg 2011;27:47-56. 